\title{
Haller Hücreleri ve Schneiderian Membran Kalınlığı Arasındaki İlişkinin Analizi
}

\section{Analysis of relationship between Haller cells and Schneiderian Membrane Thickness}

\author{
${ }^{1}$ Emrah DILAVER, ${ }^{2}$ Aslihan AKBULUT, ${ }^{1}$ Cagri DELILBASI \\ ${ }^{1}$ Department of Oral and Maxillofacial Surgery, Istanbul Medipol University School of Dentistry, Istanbul, Turkey \\ ${ }^{2}$ Department of Oral and Maxillofacial Radiology, Istanbul Medipol University School of Dentistry, Istanbul, Turkey
}

ÖZ

Amaç: Bu çalışmanın ilk amacı, Haller hücreleri varlığı ile Schneiderian membran kalınlı̆̆ 1 (SMT) arasında; yaş ve cinsiyet gibi faktörleri de göz önünde bulundurarak, bir ilişki olup olmadığını belirlemekti. Bu çalışmanın ikinci amacı ise panaromik röntgen ve konik 1şınlı bilgisayarl tomografi (CBCT)'de Haller hücrelerinin görünürlügünün korelasyonunu araştırmaktı.

Materyal ve Metot: 78 dişsiz hasta çalışmaya dahil edildi. CBCT'lerden elde edilen kesitsel görüntüler, sinüs membran kalınlığını belirlemek için kullanıldı. Cinsiyet ve yaş gibi parametreler ayrıca incelendi.

Bulgular: Haller hücresi olan ve olmayanlar arasında, maksiller sinüs tabanındaki sinüs membran kalınlığındaki fark anlamlı bulundu $(\mathrm{p}<0,05)$. Haller hücrelerinin CBCT ve dijital panoramik radyografilerde görünürlüğü arasında korelasyon bulunmuştur $(\mathrm{p}<0,01)$. Sinüs membran kalınlığı, erkeklerde kadınlardan daha yüksek görülmekle beraber bu fark anlamlı bulunmamıştır $(p>0,05)$.

Sonuç: Çalışmamızdaki sonuçlar göz önüne alındığında, Haller hücresi varlığı sinüs membranının tabanında kalınlaşmaya yol açabilmektedir. Haller hücrelerinin dijital panoramik radyografilerde de görülebilmesi nedeniyle; sinüs yükseltme cerrahisi öncesinde alınan dijital panaromik görüntü, Schneiderian membran kalınlığı hakkında klinisyenlere ameliyat öncesi ipucu verebilir.

Anahtar Kelimeler: Haller hücreleri, konik işınlı bilgisayarlı tomografi, maksiller sinus anatomisi, schneiderian membran kalınlığ

\begin{abstract}
Objective: This first aim of this study was to determine whether there is a relationship between the presence of Haller cells and Schneiderian membrane thickness (SMT) by considering factors such as age and gender. The second aim of this study was to investigate correlation between the visibility of Haller cells on cone beam computed tomography (CBCT) and digital panoramic radiographs.

Materials and Methods: Seventy-eight edentulous patients were included in the study. Cross-sectional views obtained from CBCTs were used to determine the mean sinus membrane thickness. Parameters such as gender and age were also investigated.
\end{abstract}

Results: The difference in SMT at the base of the maxillary sinus was significant between those with and without Haller cells $(p<0.05)$. A correlation was found between the detection of Haller cells on CBCT and digital panoramic radiographs $(\mathrm{p}<0.01)$. Although SMT was higher in men than in women, this difference was not significant $(\mathrm{p}>0.05)$.

Conclusion: Considering the results of our study, the presence of Haller cells may cause sinus membrane thickness at base of maxillary sinus. Since Haller cells can also be seen in digital panoramic radiographs, digital panoramic view taken prior to sinus lift surgery can provide clinicians with preoperative hint about SMT.

Keywords: Cone beam computed tomography, haller cells, maxillary sinus anatomy, schneiderian membrane thickness

\section{Sorumlu Yazar / Corresponding Author:}

Emrah Dilaver

İstanbul Medipol University School of Dentistry, Department of

Oral and Maxillofacial Surgery, Atatürk Bulvarı No:27, 34083

Unkapani-Istanbul

Tel: +902124608749

E-mail: emrahdilaver@gmail.com
Yayın Bilgisi / Article Info:

Gönderi Tarihi/ Received: 07/12/2020

Kabul Tarihi/ Accepted: 01/01/2021

Online Yayın Tarihi/ Published: 05/03/2021

Atıf / Cited: Dilaver E, et al. Analysis of relationship between Haller cells and Schneiderian Membrane Thickness. Online Türk Sağllk Bilimleri Dergisi 2021;6(1):12-21. doi: 10.26453/otjhs.836273 


\section{INTRODUCTION}

Sinus lifting procedure is a commonly performed option in dentistry to increase bone height in the posterior maxilla. During this procedure, Schneiderian membrane should be kept intact as much as possible to reduce infection risk and to provide good clinical results. ${ }^{1-3}$ Perforation of this membrane is the most encountered perioperative complication during sinus grafting $(19.8 \%){ }^{4}$

Normal Schneiderian membrane thickness (SMT) is approximately $0.8-1 \mathrm{~mm}$, however; SMT increases if there is an irritation factor such as infection and allergy. ${ }^{5}$ Preoperative prediction of sinus membrane thickness may be practically important for sinus lifting surgery to prevent membrane perforation and postoperative complications. ${ }^{6,7}$ Schneiderian membrane thickness (SMT) was found to be an important anatomic factor in perforation and implant failure. ${ }^{8-10}$ In previous studies stated that there was lower perforation risk when sinus membrane was thicker than $2 \mathrm{~mm} .{ }^{8,11,12}$ However, Lu Yi et al. ${ }^{13}$ reported that $2 \mathrm{~mm}$ sinus membrane thickness being a criteria to determine pathologic state.

Haller cells which are located anterior extension of ethmoidal sinuses are the anatomical variation of paranasal sinuses. ${ }^{14}$ Mucociliary flow can be disrupted in case of large sized Haller cells which can be responsible for compression on maxillary sinus infundubulum. Disruption $f$ mucociliary flow produce favourable enviroment for bacterial growth. ${ }^{15}$ There were some studies stated that presence of Haller cells is a risk factor for maxillary sinusitis. ${ }^{16,17}$ What remains unclear in the literature is whether SMT may be affected by presence of Haller cells.

In the present study we evaluated relationship between Schneiderin membrane thickness and presence of Haller cells to contribute to our understanding of how factors such as age and gender affect the membrane thickness. The second aim of this study was to determine the detectability of Haller cells on digital panoramic radiograph and cone beam computed tomography (CBCT).

\section{MATERIALS AND METHODS}

This study was approved from the ethics committees of Istanbul Medipol University on where the study was conducted (Date: 19.08.2019, decision no: 10840098-604.01.01-E.41127). All procedures performed in this retrospective study involving human's data were in accordance with the ethical standards of the institutional committee and with the $1964 \mathrm{Hel}-$ sinki declaration and its later amendments or comparable ethical standards

This retrospective study evaluated the CBCTs obtained from the patients who had undergone sinus lifting procedure in the posterior maxilla.

The CBCT images were obtained using the I-CAT 3D Imaging System (Imaging Sciences International, Inc., Hatfield, PA, USA) with the following parameters: $120 \mathrm{kVp}$ and $20.27 \mathrm{mAs}$ using a $16-\times$ $11-\mathrm{cm}$ field of view and 0.25 voxel.

Patients with a history of dental implant placement or bone grafting in the posterior maxilla, history of maxillary sinusitis, sinonasal tumors, nasal polyposis, previous nasal surgery and having any teeth incontact with the maxillary sinus in the evaluated sinus area were excluded from the study samples.

The CBCT images were evaluated by an experienced radiologist (AA). Image measurements for all parameters were performed with I-CAT Vision software (Imaging Science International).

Panoramic sections were used to obtain crosssectional views from CBCTs. On panoramic view, we obtained a total of 10 cross-sectional images at $2.5 \mathrm{~mm}$ intervals (anterior to posterior) starting from anterior slices of maxillary sinus that corresponds to root tips of the maxillary first premolar to posterior areas in edentulous patients (Figure 1). We measured three points on per 10 cross-sectional images which were midmost point of the lateral maxillary sinus wall (Figure 2a), the deepest point of the maxillary sinus floor (Figure 2b) and the intersection point of nasal the cavity and maxillary sinus (Figure 2c). The arithmetic means of 10 cross-sectional images to calculate mean thickness of per sinus membrane were recorded for each previously described point.

Presence of Haller cells, which were located at roof of the maxillary sinus (MS) and above the maxillary sinus ostium was noted (Figure 3 ). Gender, age and whether Haller cells are visible in previously taken digital panoramic radiographs were also recorded (Figure 4).

Statistical Analysis: All data were transferred to Statistical Package for the Social Sciences (SPSS for Windows, version 18.0, SPSS Inc., Chicago, USA) and descriptive analysis was performed and means, standard deviations were reported. The significance level for all statistical tests was $\mathrm{p} \leq 0.05$. Where appropriate, an independent sample $t$ test was used for statistical comparisons between the two groups. When statistical differences were observed by using 
ANOVA, a post hoc Tukey's test was performed to determine which groups differed. A Spearman or Pearson correlation was performed to analyze the correlation between two variables, as appropriate.

\section{RESULTS}

A total of 78 patients (33 males, 45 females) with a mean age of 50.88 years $( \pm 11.9)$ were included in this study. One hundred and one maxillary sinuses (49 right and 52 left side) were investigated. Haller cells were found in $67.9 \%$ patients; of these 15 (19.2\%) were bilaterally, 38 (48.7\%) were unilaterally.

The mean SMT in males was $2.98 \pm 1.22 \mathrm{~mm}$ at maxillary sinus floor, $2,30 \pm 1.01 \mathrm{~mm}$ at midmost point of the maxillary sinus wall and $2.56 \pm 0.96 \mathrm{~mm}$ at intersection point between the maxillary sinus floor and nasal cavity. These values in females were $2.87 \pm 1.14 \mathrm{~mm}, 1.92 \pm 1.23 \mathrm{~mm}$ and $2.1 \pm 1.07 \mathrm{~mm}$, respectively. The results showed that, mean values were higher in males than that of females, however, this difference was not found significant $(p>0.05)$

Based on the results of the analysis, the mean thickness of the right sinus membrane in patients having Haller cells was $2.92 \pm 1.24 \mathrm{~mm}$ at maxillary sinus floor, $2.09 \pm 0.99 \mathrm{~mm}$ at midpoint of lateral maxillary sinus wall and $2.25 \pm 0.82 \mathrm{~mm}$ at intersection point between floor of MS and nasal cavity. These values which were measured in patients without Haller cells were $2.21 \pm 0.89 \mathrm{~mm}, 1.9 \pm 1.03 \mathrm{~mm}$ and $2.13 \pm 0.96$ $\mathrm{mm}$ respectively. There was significant difference between presence of Haller cells and sinus membrane thickness at maxillary sinus floor $(p=0.026)$. However; sinus membrane thickness at buccal and medial side was not significant between patients with Haller cells and between those not having $(\mathrm{p}>0.05)$ (Table 1$)$.

The average mean value of the left maxillary sinus membrane thickness in patients having Haller cells was $3.78 \pm 1.22 \mathrm{~mm}$ at maxillary sinus floor, $2.2 \pm 1.36$ $\mathrm{mm}$ at midpoint of lateral maxillary sinus wall and $2.62 \pm 1.27 \mathrm{~mm}$ at intersection point between floor of maxillary sinus and nasal cavity. These values in left maxillary sinus without Haller cells were $2.54 \pm 1.30$ $\mathrm{mm}, 2.00 \pm 1.07$ and $2.06 \pm 1.03 \mathrm{~mm}$ in maxillary sinus floor, midpoint of lateral maxillary sinus wall, intersection point between floor of maxillary sinus, respectively. As on the right side, there was a significant association between presence of Haller cells and sinus membrane thickness at floor of the maxillary sinus $(\mathrm{p}=0.000)$. These values at buccal side and medial side were not significant $(\mathrm{p}>0.05)$ (Table 1)
Correlation using Pearson test revealed no significant difference between age and $\operatorname{SMT}(p>0.05)$. We also found positive correlation detecting the Haller cells between CBCT and digital panoramic radiographs $(\mathrm{p}<0.01, \mathrm{r}: 0.696)$.

\section{DISCUSSION AND CONCLUSION}

Preoperative knowledge of SMT is very important to avoid sinus membrane perforation during sinus lifting procedure. ${ }^{6}$ SMT may be affected by factors such as gender, smoking status, proximity to endodontic or periodontal lesions, presence of septa, and gingival phenotype. ${ }^{18}$ In previous studies; older people have thicker sinus membrane because they may suffer from more chronic disease than younger people. ${ }^{19-21}$ In the present study, we found that sinus membrane thickness did not correlate with age. Our results come in accordance with some previous studies. $^{22,23}$

The gender has a significant effect on SMT in other studies. Mean SMT was higher in males than females $^{22,23}$, which was compatible in our study findings. However; we did not find significant difference in measurements between males and females, which was consistent with Pazara et al. ${ }^{24}$ $(p=0.294)$.

There were other studies investigating effect of different factors on SMT. Aimetti et al. ${ }^{1}$ studied 20 subjects via histological measurement and found that there was a correlation between gingival phenotype and SMT. Yoo JY et al. ${ }^{25}$ found that SMT values were higher in patients having periodontal disease. However; there was no significant difference in patients with and without periodontal disease. We did not examine effect of periodontal status because our patients were edenteleous in the posterior maxilla. Another CBCT study included 199 sinus lift procedures that found that SMT was higher than $2 \mathrm{~mm}$ in patients with missing posterior teeth. ${ }^{26}$ The mean thickness of SMT in our study was higher than 2 $\mathrm{mm}$ at three investigated point both right and left maxillary sinuses.

Haller cells which are located between maxillary sinus and orbit are possible etiologic factors in maxillary sinusitis due to their narrowing the osteomeatal complex. ${ }^{27}$ As a result, mucociliary flow can be disrupted. It can be therefore assumed that presence of Haller cells may cause to SMT. In the present study; we investigated possible relation between sinus membrane and presence of Haller cells. Mean membrane thicknesses at floor of maxillary sinus for both right and left sides were 
higher in patients with having Haller cells on the same side compared to those not. This difference was significant $(p<0.05)$, however other investigated parameters were not significant $(\mathrm{p}>0.05)$.

In conclusion, our results showed that Haller cells may be anatomic variants leading to Schneiderian membrane thickening at base of maxillary sinus. We may have knowledge about Schneiderian membrane thickness before sinus lifting procedure if we detect Haller cells on digital panoramic radiographs because positive correlation was found between appearance of Haller cells in CBCT with digital panoramic radiographs.

Ethics Committee Approval: Our study was approved by the Istanbul Medipol University Ethics Committee (Date:19.08.2019, decision no: 10840098-604.01.01-E.41127).

Conflict of Interest: No conflict of interest was declared by the authors.

Author Contributions: Concept -ED; Supervision ED, BCD; Materials -ED,AA; Data Collection and Processing - ED, AA; Analysis and Interpretation E.D; Writing - ED

Peer-review: Externally peer-reviewed.

\section{REFERENCES}

1. Aimetti M, Massei G, Morra M, Cardesi E, Romano F. Correlation between gingival phenotype and Schneiderian membrane thickness. Int J Oral Maxillofac Implants. 2008;23(6):11281132.

2. Proussaefs P, Lozada J, Kim J, Rohrer MD. Repair of the perforated sinus membrane with a resorbable collagen membrane: a human study. Int J Oral Maxillofac Implants. 2004;19(3):413420.

3. Wiltfang J, Schultze-Mosgau S, Merten HA, Kessler P, Ludwig A, Engelke W. Endoscopic and ultrasonographic evaluation of the maxillary sinus after combined sinus floor augmentation and implant insertion. Oral Surg, Oral Med, Oral Pathol, Oral Radiol. 2000;89(3):288-291.

4. Pjetursson BE, Tan WC, Zwahlen M, Lang NP. A systematic review of the success of sinus floor elevation and survival of implants inserted in combination with sinus floor elevation. J Clin Periodontol. 2008;35(8):216-240.

5. Goller-Bulut D, Sekerci AE, Kose E, Sisman Y. Cone beam computed tomographic analysis of maxillary premolars and molars to detect the relationship between periapical and marginal bone loss and mucosal thickness of maxillary sinus. Med Oral, Patol Oral Cir Bucal. 2015;20 (5):572-579.

6. Yilmaz HG, Tozum TF. Are gingival phenotype, residual ridge height, and membrane thickness critical for the perforation of maxillary sinus? J Periodontol. 2012;83(4):420-425.

7. Pommer B, Unger E, Suto D, Hack N, Watzek G. Mechanical properties of the Schneiderian membrane in vitro. Clin Oral Implants Res. 2009;20 (6):633-637.

8. Garcia-Denche JT, Wu X, Martinez PP, et al. Membranes over the lateral window in sinus augmentation procedures: a two-arm and split-mouth randomized clinical trials. J Clin Periodontol. 2013;40(11):1043-1051.

9. Berengo M, Sivolella S, Majzoub Z, Cordioli G. Endoscopic evaluation of the bone-added osteotome sinus floor elevation procedure. Int $\mathrm{J}$ Oral and Maxillofac Surg. 2004;33(2):189-194.

10. van den Bergh JP, ten Bruggenkate CM, Disch FJ, Tuinzing DB. Anatomical aspects of sinus floor elevations. Clin Oral Implants Res. 2000;11 (3):256-265.

11.Lin YH, Yang YC, Wen SC, Wang HL. The influence of sinus membrane thickness upon membrane perforation during lateral window sinus augmentation. Clin Oral Implants Res. 2016;27 (5):612-617.

12. Wen SC, Lin YH, Yang YC, Wang HL. The influence of sinus membrane thickness upon membrane perforation during transcrestal sinus lift procedure. Clin Oral Implants Res. 2015;26 (10):1158-1164.

13. Lu Y, Liu Z, Zhang L, et al. Associations between maxillary sinus mucosal thickening and apical periodontitis using cone-beam computed tomography scanning: a retrospective study. J Endod. 2012;38(8):1069-1074.

14. Yanagisawa E, Marotta JC, Yanagisawa K. Endoscopic view of a mucocele in an infraorbital ethmoid cell (Haller cell). Ear Nose Throat j. 2001;80(6):364-368.

15. Kamdi P, Nimma V, Ramchandani A, Ramaswami E, Gogri A, Umarji H. Evaluation of haller cell on $\mathrm{CBCT}$ and its association with maxillary sinus pathologies. J Indian Acad Oral Med Radiol. 2018;30(1):41-45.

16. Ali IK, Sansare K, Karjodkar FR, Vanga K, Salve P, Pawar AM. Cone-beam computed tomography analysis of accessory maxillary ostium 
and Haller cells: Prevalence and clinical significance. Imaging Sci Dent. 2017;47(1):33-37.

17. Stackpole SA, Edelstein DR. The anatomic relevance of the Haller cell in sinusitis. Am J Rhinol. 1997;11(3):219-224.

18. Bornstein MM, Wasmer J, Sendi P, Janner SF, Buser D, von Arx T. Characteristics and dimensions of the Schneiderian membrane and apical bone in maxillary molars referred for apical surgery: a comparative radiographic analysis using limited cone beam computed tomography. J Endod. 2012;38(1):51-57.

19. Monje A, Diaz KT, Aranda L, Insua A, GarciaNogales A, Wang HL. Schneiderian membrane thickness and clinical implications for sinus augmentation: a systematic review and metaregression analyses. J Periodontol. 2016;87 (8):888-899.

20. Maska B, Lin GH, Othman A, et al. Dental implants and grafting success remain high despite large variations in maxillary sinus mucosal thickening. Int J Implant Dent. 2017;3(1):1-8.

21. Ren S, Zhao H, Liu J, Wang Q, Pan Y. Significance of maxillary sinus mucosal thickening in patients with periodontal disease. Int Dent $\mathrm{J}$. 2015;65(6):303-310.

22. Janner SF, Caversaccio MD, Dubach P, Sendi P, Buser D, Bornstein MM. Characteristics and dimensions of the Schneiderian membrane: a radiographic analysis using cone beam computed tomography in patients referred for dental implant surgery in the posterior maxilla. Clin Oral Implants Res. 2011;22(12):1446-1453.

23. Yildirim TT, Guncu GN, Goksuluk D, Tozum MD, Colak M, Tozum TF. The effect of demographic and disease variables on Schneiderian membrane thickness and appearance. Oral Surg, Oral Med, Oral Pathol, Oral Radiol. 2017;124 (6):568-576.

24. Pazera P, Bornstein MM, Pazera A, Sendi P, Katsaros C. Incidental maxillary sinus findings in orthodontic patients: a radiographic analysis using cone-beam computed tomography (CBCT). Orthod Craniofac Res 2011;14(1):17-24.

25. Yoo JY, Pi SH, Kim YS, Jeong SN, You HK. Healing pattern of the mucous membrane after tooth extraction in the maxillary sinus. J Periodontal Implant Sci. 2011;41(1):23-29.

26. Shanbhag S, Karnik P, Shirke P, Shanbhag V. Cone-beam computed tomographic analysis of sinus membrane thickness, ostium patency, and residual ridge heights in the posterior maxilla: implications for sinus floor elevation. Clin Oral Implants Res. 2014;25(6):755-760.

27.Zinreich SJ, Kennedy DW, Rosenbaum AE, Gayler BW, Kumar AJ, Stammberger H. Paranasal sinuses: CT imaging requirements for endoscopic surgery. Radiology. 1987;163(3):769-775. 
Table 1. Representive data of patients with and without haller cells (values shown as mean $\pm \mathrm{SD}$ ).

\begin{tabular}{|c|c|c|c|c|}
\hline & $\begin{array}{c}\text { Investigated } \\
\text { points }\end{array}$ & $\begin{array}{c}\text { Presence of } \\
\text { Haller cells }\end{array}$ & $\begin{array}{c}\text { Absence of } \\
\text { Haller cell }\end{array}$ & p \\
\hline \multirow{3}{*}{ SMT right maxillary sinus } & $\mathrm{a}$ & $2.09 \pm 0.99$ & $1.9 \pm 1.03$ & 0.604 \\
\cline { 2 - 5 } & $\mathrm{b}$ & $2.92 \pm 1.24$ & $2.21 \pm 0.89$ & $0.026^{*}$ \\
\cline { 2 - 5 } & $\mathrm{c}$ & $2.25 \pm 0.82$ & $2.13 \pm 0.96$ & 0.640 \\
\hline \multirow{3}{*}{ SMT at left maxillary sinus } & $\mathrm{a}$ & $2.2 \pm 1.36$ & $2.00 \pm 1.07$ & 0.404 \\
\cline { 2 - 5 } & $\mathrm{b}$ & $3.78 \pm 1.22$ & $2.54 \pm 1.30$ & $0.000^{*}$ \\
\cline { 2 - 5 } & $\mathrm{c}$ & $2.62 \pm 1.27$ & $2.06 \pm 1.03$ & 0.71 \\
\hline
\end{tabular}

*:Statistically significant; a: Middle point of lateral maxillary sinus wall; b: The deepest point of maxillary sinus floor; c: The intersection point of nasal cavity and maxillary sinus; SMT: Sinus membrane thickening. 


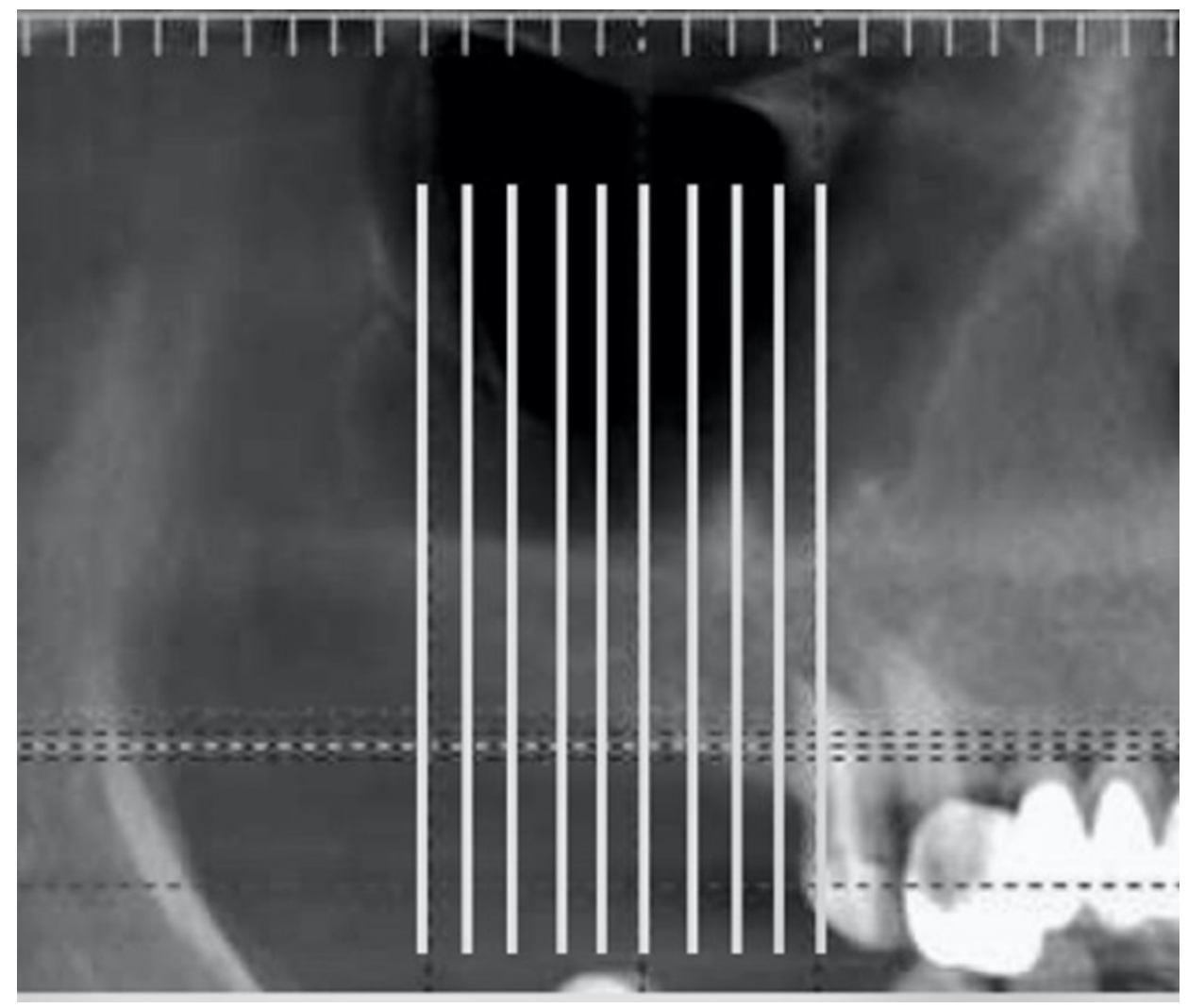

Figure 1. Representation of the locations where 10 cross-sectional images were taken on CBCT's panaromic section. 


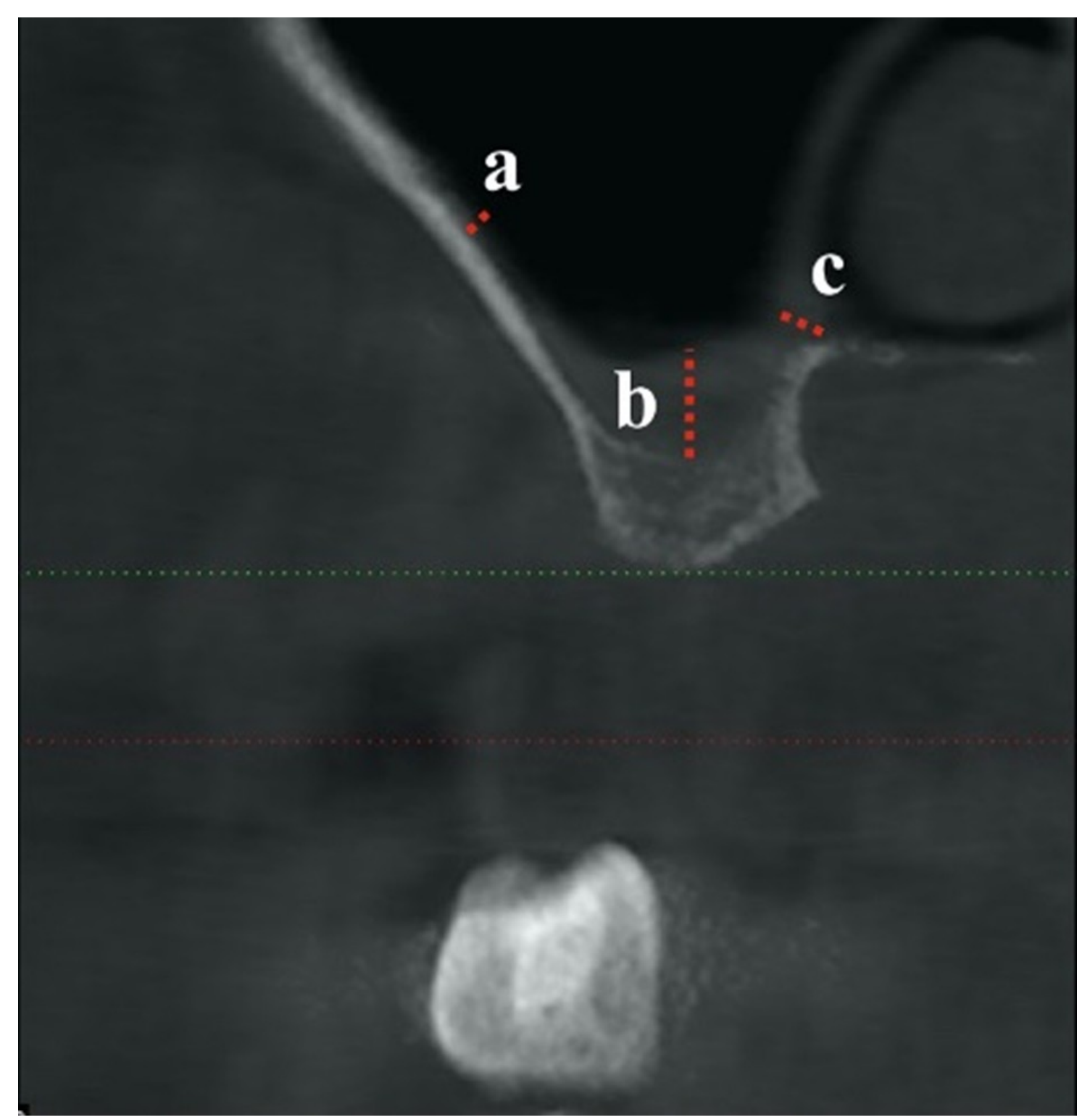

Figure 2. The points that used for Schnederian membrane thickness. a: The midmost point of lateral maxillary sinus wall, b: The deepest point of maxillary sinus floor; $\mathrm{c}$ : The intersection point of nasal cavity and maxillary sinus. 


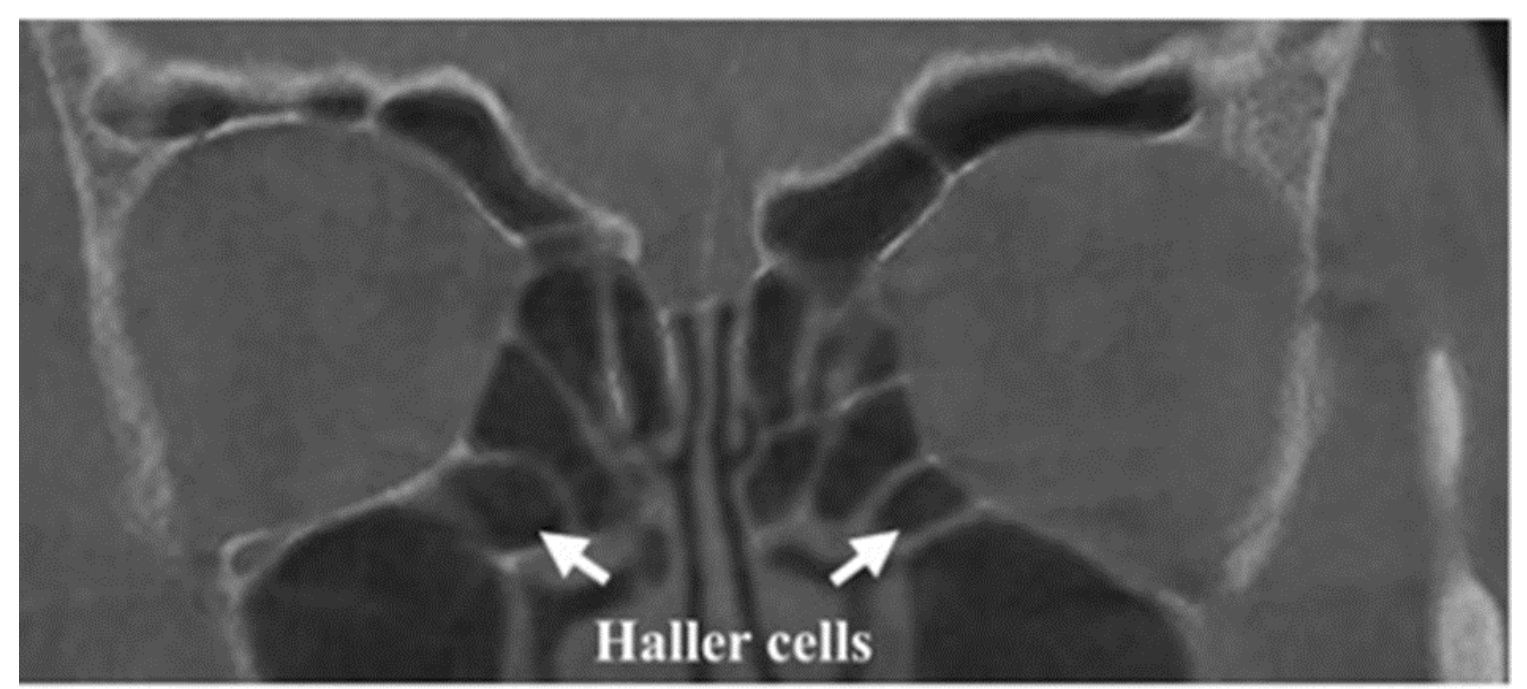

Figure 3. Detection of haller cells on CBCT. 


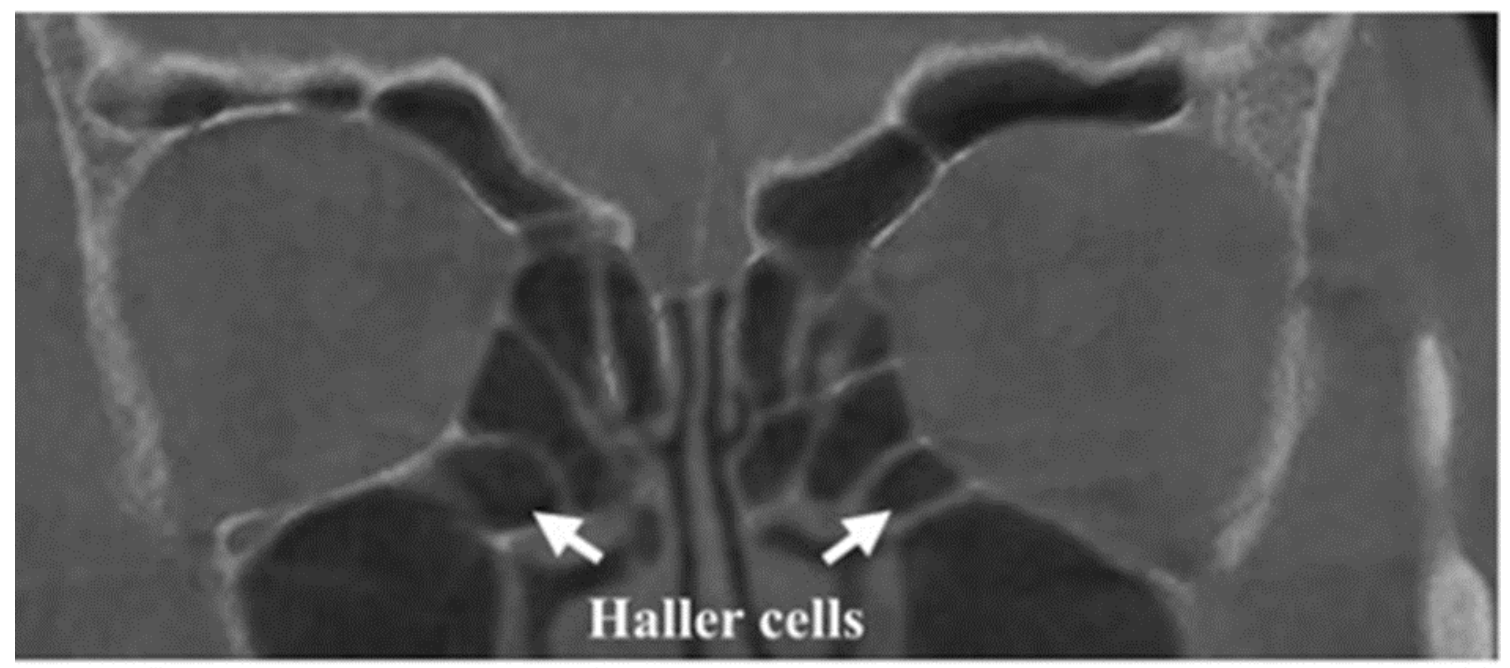

Figure 4. Detection of haller cells on panoramic radiograph. 